\title{
Experience of hysteroscopy in a rural tertiary care center of Haryana, India
}

\author{
Manisha Upadhyay ${ }^{1 *}$, Tek C. Yadav ${ }^{2}$, Pinkey Lakra ${ }^{1}$, Sunita Siwach ${ }^{1}$, \\ Rajiv Mahendru ${ }^{1}$, Vijayata Sangwan ${ }^{1}$
}

\begin{abstract}
${ }^{1}$ Department of Obstetrics and Gynecology, Bhagat Phool Singh Govt. Medical College for Women, Khanpur Kalan, Sonepat, Haryana, India

${ }^{2}$ Department of Medicine, Bhagat Phool Singh Govt. Medical College for Women, Khanpur Kalan, Sonepat, Haryana, India
\end{abstract}

Received: 17 July 2019

Accepted: 07 September 2019

\section{*Correspondence:}

Dr. Manisha Upadhyay,

E-mail: docmanisha.u@gmail.com

Copyright: () the author(s), publisher and licensee Medip Academy. This is an open-access article distributed under the terms of the Creative Commons Attribution Non-Commercial License, which permits unrestricted non-commercial use, distribution, and reproduction in any medium, provided the original work is properly cited.

\section{ABSTRACT}

Background: During the last few decades hysteroscopy has become a tool of choice for evaluation of uterine cavity due to its "see and treat "benefits. It is more accurate and less invasive. Introduction of hysteroscopy in gynecological practice is the need of time. Aim of our study is to share the experience of hysteroscopy, its learning curve and limitations in a rural tertiary care center of Haryana.

Methods: We retrospectively analyzed all the hysteroscopy procedure done from January 2016 to December 2018 from the hospital records.

Results: Total 118 hysteroscopy were done but record of only 110 was available. Out of 110, 37(33\%) were operative and $73(67 \%)$ were diagnostic. $36 \%$ were done for AUB, $33 \%$ for infertility, $15 \%$ for misplaced cu t, $6 \%$ for amenorrhea, $2 \%$ in cases of RPL and rest for some less common indications. Out of operative hysteroscopy major procedures done were polypectomy and removal of misplaced $\mathrm{Cu}-\mathrm{T}$. Septal resection was also done in 3 cases. Number of operative hysteroscopy has increased over the time period of study.

Conclusions: Hysteroscopic evaluation of uterine cavity is a reliable method for both diagnostic and treatment purpose. Proportion of hysteroscopy procedures and its learning curve will improve with persistent effort.

Keywords: AUB, Diagnostic hysteroscopy, Hysteroscopy, Learning curve, Operative hysteroscopy, See and treat

\section{INTRODUCTION}

Hysteroscopy has revolutionized the approach towards management of intrauterine diseases due to its see and treat potential. It is an accurate, less invasive and cost effective option for the evaluation of common gynecological disorders such as premenopausal or postmenopausal abnormal uterine bleeding (AUB), endometrial hyperplasia, endometrial cancer and infertility. ${ }^{1}$ It allows the direct visualization of the endometrial and endocervical cavity. It is a dynamic test and allows a direct visualization of the endocervical and endometrial cavity revealing the nature, location, shape, size and vascular pattern of any pathology. ${ }^{2}$

Today is the era of office hysteroscopy because of high patient satisfaction rate, reduced need for anesthesia, decreased cost and more compliance. ${ }^{3}$ That is why 
introduction of hysteroscopy in gynecological practice is the need of time. Along with its multiple advantages it has long learning curve and require specific training which create hurdle for the beginners. The learning curve will improve with persistent efforts.

Aim of our study is to share our experience of hysteroscopy, learning curve and limitations faced in a rural tertiary care center of Haryana. Retrospective analysis of our work helps us in overcoming the flaws and motivates for the improvement in future.

\section{METHODS}

This retrospective observational study was carried out in the department of obstetrics and gynecology of a rural tertiary care center of Haryana. We collected and analyzed all the cases of hysteroscopy done from January 2016 to December 2018 with the help of hospital records. Total 118 cases of hysteroscopy were done during January 2016 to December 2018. Eight cases were excluded from the study due to unavailability of complete record. All the cases recorded were theatre hysteroscopy.
Parameters studied were age, parity, indication of hysteroscopy, type of hysteroscopy (diagnostic/operative), hysteroscopy findings, therapeutic interventions done by hysteroscopy, complications and hurdles/limitations faced in our rural tertiary care center while pursuing hysteroscopy.

\section{Statistical analysis}

Recorded data was analyzed using SPSS version 22 and expressed in the form of numbers, percentages and graphs.

\section{RESULTS}

The age of the patients in the study ranged from 20-62 years and the mean age came out to be 33.2 years. Maximum patients (80 out of 110) lied between 20-39 years and only 6 patients were above 50 years. Out of $110,87(79 \%)$ patients were multiparous.

Table 1: Distribution of diagnostic and operative hysteroscopy over three years (January 2016 - December 2018 ).

\begin{tabular}{|llll|}
\hline $\begin{array}{|ll|}\text { Year (January 2016 - } \\
\text { December 2018) }\end{array}$ & Total no. of hysteroscopy & Diagnostic hysteroscopy & Operative hysteroscopy \\
\hline 2016 & 33 & $24(72.72 \%)$ & $9(27.27 \%)$ \\
\hline 2017 & 37 & $25(67.56 \%)$ & $12(32.43 \%)$ \\
\hline 2018 & 40 & $24(56.76 \%)$ & $16(43.24 \%)$ \\
\hline
\end{tabular}

Table 2: Various indications of hysteroscopy and their percentage found in retrospective analysis.

\begin{tabular}{|lll|}
\hline $\begin{array}{l}\text { Indications of } \\
\text { hysteroscopy (January } \\
\text { 2016 - December 2018) }\end{array}$ & $\begin{array}{l}\text { Frequency } \\
(\mathrm{N}=110)\end{array}$ & Percentage \\
\hline AUB & 40 & $36.36 \%$ \\
\hline Primary infertility & 19 & $17.27 \%$ \\
\hline Secondary infertility & 18 & $16.36 \%$ \\
\hline Misplaced IUCD & 17 & $15.45 \%$ \\
\hline Secondary amenorrhea & 7 & $6.36 \%$ \\
\hline RPL & 2 & $1.81 \%$ \\
\hline PMB & 6 & $5.45 \%$ \\
\hline Foreign body uterus & 1 & $0.91 \%$ \\
\hline
\end{tabular}

Among the 110 hysteroscopy, 37 (33\%) were operative and $73(67 \%)$ were diagnostic. Table 1 shows the distribution of diagnostic and operative hysteroscopy over three years (January 2016 - December 2018).

Most common indication of hysteroscopy was found to be AUB (36\%) followed by infertility (33\%). Table 2 shows the various indications for which hysteroscopy were done.

Table 3: Pattern of hysteroscopy findings.

\begin{tabular}{|lll|}
\hline Findings & $\begin{array}{l}\text { Frequency } \\
(\mathrm{N}=110)\end{array}$ & Percentage \\
\hline Normal & 39 & $35.45 \%$ \\
\hline Endometrial polyp & 14 & $12.72 \%$ \\
\hline Polypoidal endometrium & 5 & $4.54 \%$ \\
\hline Hyperplastic endometrium & 12 & $10.9 \%$ \\
\hline Atrophic endometrium & 4 & $3.63 \%$ \\
\hline Small cavity & 5 & $4.54 \%$ \\
\hline Congested cavity & 1 & $2.7 \%$ \\
\hline Intracavitary adhesions & 3 & $2.7 \%$ \\
\hline Blocked ostia & 7 & $6.36 \%$ \\
\hline Deep seated ostia & 1 & $0.91 \%$ \\
\hline IUCD & 15 & $13.63 \%$ \\
\hline $\begin{array}{l}\text { Fetal bony chips } \\
\text { embedded in endometrium }\end{array}$ & 2 & $1.8 \%$ \\
\hline Septum & Complete-3 & $7.27 \%$ \\
\hline Submucus fibroid & 5 & $4.54 \%$ \\
\hline Endocervical polyp & 3 & $2.72 \%$ \\
\hline
\end{tabular}


As depicted in Table 3 out of 110 patients who underwent hysteroscopy, 3 (35.45\%) didn't have any abnormalities, $57(51 \%)$ had intrauterine pathologies and rest had foreign bodies like fetal bony chips or IUCD.

Table 4: Operative procedures done hysteroscopically.

\begin{tabular}{|ll|}
\hline Operative procedure & No. of patients $(\mathrm{N}=37)$ \\
\hline Polypectomy & $13(35 \%)$ \\
\hline Removal of cu T & $15(13.63 \%)$ \\
\hline Hysteroscopic adhesiolysis & $2(1.8 \%)$ \\
\hline Hysteroscopic canulation & $2(1.8 \%)$ \\
\hline Removal of fetal bony chips & $2(1.8 \%)$ \\
\hline Septal resection & $3(1.8 \%)$ \\
\hline
\end{tabular}

Operative hysteroscopy was done in 37 patients. Table 4 shows the operative procedures done hysteroscopically.

Table 5: complications happened during hysteroscopy.

\begin{tabular}{|ll|}
\hline Complications & In total $(\mathrm{N}=110)$ patient \\
\hline Total complications & $3(2.7 \%)$ \\
\hline Uterine perforation & $1(0.9 \%)$ \\
\hline $\begin{array}{l}\text { Post procedure adhesion } \\
\text { formation in metroplasty }\end{array}$ & $1(0.9 \%)$ \\
\hline Pulmonary embolism & $1(0.9 \%)$ \\
\hline
\end{tabular}

Three patients had complications while doing hysteroscopy as shown in Table 5. All the complications happened during operative hysteroscopy.

\section{DISCUSSION}

Hysteroscopy is a boon to this modern era due to its see and treat benefits. It is a gold standard diagnostic and therapeutic approach for intrauterine pathologies.

Age distribution of patients in our analysis suggests that hysteroscopy has not been chosen as a preferred method of diagnosis in perimenopausal and postmenopausal patients inspite of its dual advantage of direct visualization and biopsy for histopathological examination at the same time. Now it's the time to shift from sticking only to histopathology to hysteroscopy for diagnosis of intrauterine pathologies even in postmenopausal women. Daniilidis et al and Elbareg et al have also emphasized on the use of hysteroscopy as a preferred method for diagnosis of intrauterine pathologies in perimenopausal and postmenopausal women. ${ }^{1,2}$

Most common indication for hysteroscopy in our study was found to be AUB which is in agreement with other studies done by Tangri et al, Gulumser et al and Emovon et al. But there is a disagreement among these researchers regarding the other common indications. In our study infertility is the second most common indication which is in agreement with the observation of Tangri et al while in the studies done by Gulumser et al and Emovon et al postmenopausal bleeding was the second most common indication which might be due to the liberal acceptance of hysteroscopy for diagnosis of abnormal uterine bleeding in postmenopausal women in western countries. ${ }^{3-5}$

Table 6: Comparison of pattern of hysteroscopy findings of our study with other two studies.

\begin{tabular}{|lcll|}
\hline $\begin{array}{l}\text { Hysteroscopic } \\
\text { findings }\end{array}$ & $\begin{array}{c}\text { Our } \\
\text { study }\end{array}$ & $\begin{array}{l}\text { Tangri } \\
\text { et al, }\end{array}{ }^{1}$ & $\begin{array}{l}\text { Kathuria } \\
\text { et al, }{ }^{4}\end{array}$ \\
\hline NAD & $32 \%$ & $69 \%$ & $22 \%$ \\
\hline $\begin{array}{l}\text { Endometrial polyp } \\
20 \%\end{array}$ & $8 \%$ & $14 \%$ \\
\hline $\begin{array}{l}\text { Polypoidal and } \\
\text { hyperplastic } \\
\text { endometrium }\end{array}$ & $30 \%$ & $0.5 \%$ & $38 \%$ \\
\hline Submucus fibroid & $10 \%$ & $9.7 \%$ & $20 \%$ \\
\hline Arcuate uterus & $2.5 \%$ & - & - \\
\hline Endocervical polyp & $5 \%$ & $1.8 \%$ & \\
\hline
\end{tabular}

Table 6 shows the comparison of pattern of hysteroscopy findings of our study with other two studies done by Tangri et al and Kathuria et al.,

Table 6: Comparison of complications during hysteroscopy in our study with other two studies.

\begin{tabular}{|llll|}
\hline Complication & $\begin{array}{l}\text { Our } \\
\text { study }\end{array}$ & $\begin{array}{l}\text { Deora et } \\
\mathrm{al}^{6}\end{array}$ & $\begin{array}{l}\text { Pasini et } \\
\mathrm{al}^{7}\end{array}$ \\
\hline $\begin{array}{l}\text { Total complication } \\
\text { rate }\end{array}$ & $2.7 \%$ & $0.9 \%$ & $13.6 \%$ \\
\hline Uterine perforation & $0.9 \%$ & $0.76 \%$ & $1.76 \%$ \\
\hline Pulmonary embolism & $0.9 \%$ & - & - \\
\hline $\begin{array}{l}\text { Post metroplasty } \\
\text { adhesion }\end{array}$ & $0.9 \%$ & - & - \\
\hline Fluid overload & - & $0.3 \%$ & $5 \%$ \\
\hline
\end{tabular}

Complications due to hysteroscopy are relatively rare events. They usually occur when contraindications for procedure are ignored, proper surgical techniques are not followed or equipment is used in an inappropriate fashion, but they can also occur even if the procedure has been performed correctly on well-chosen patients. ${ }^{7,8}$ Complication rate of our study was $2.7 \%$. We compared the complication rate of our study with other two studies done by Deora et al and Pasini et al, as shown in Table 7., ${ }^{9,10}$ Complications occur more frequently with operative hysteroscopy than with diagnostic hysteroscopy as we also saw in our study. All the three complications happened in operative hysteroscopy. One patient had uterine perforation while removal of submucous myoma. Procedure abandoned immediately and patient managed conservatively. Uterine perforation is the commonest complication of hysteroscopic surgery. Uterus can be perforated during dilatation or with hysteroscope. Cervical stenosis, severe uterine anteflexion or retroflexion, synechiae, myoma resection, endometrial resection, septa division and operator inexperience, all increase the risk of perforation. ${ }^{11}$ Another patient had pulmonary embolism who had sudden collapse 
intraoperatively and died. None of our patient had fluid overload. This might due to use of endomat.

Hysteroscopy has proven advantage over other diagnostic and therapeutic modalities for intrauterine pathologies but it has a long learning curve for operative procedures. Limitation we faced in our institution over the period of time in doing hysteroscopy were:

- Non availability of instruments

- Lack of energy source

- Scarcity of mentors as ours is a new medical college

- Unexperienced OT staff

But with continuous efforts and trainings we tried to overcome these limitations. By dealing with the technical difficulties, continuous practice and learning we have tried to increase the rate of operative hysteroscopy with time as depicted in Figure 1 but we are still in evolutionary phase.

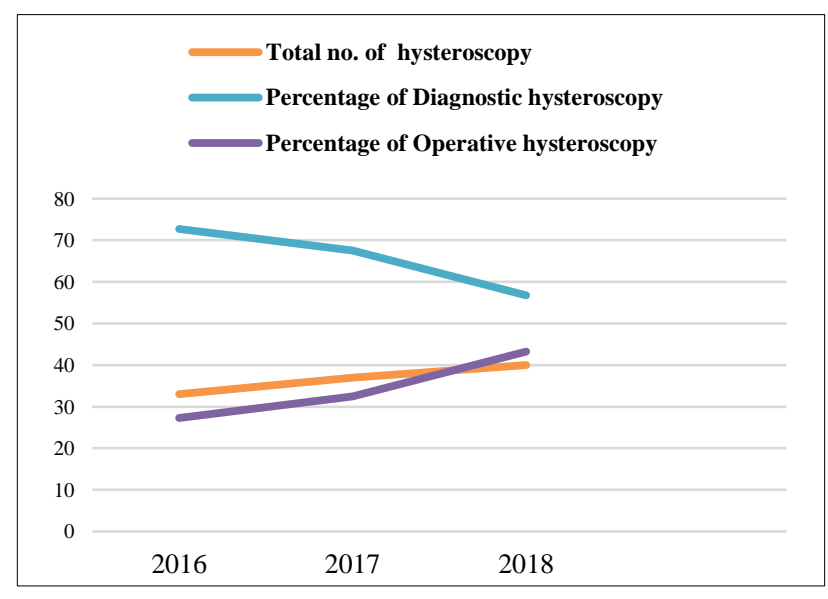

Figure 1: Rising trend of operative hysteroscopy.

\section{CONCLUSION}

Hysteroscopy is the best diagnostic and therapeutic modality for intrauterine pathologies. Persistent efforts and learning will help you moving on through your learning curve. The main purpose of sharing our experiences and limitations is to motivate the beginners. Start with small and simple procedures, keep on going, be careful and you will master the art of doing hysteroscopy.

\section{ACKNOWLEDGMENTS}

Authors would like to thank to medical record officer for being very helpful in providing records of the patient who underwent hysteroscopy.
Funding: No funding sources

Conflict of interest: None declared

Ethical approval: Not required

\section{REFERENCES}

1. Daniilidis A, Pantelis A, Dinas K, Tantanasis T, Loufopoulos PD, Angioni S, et al. Indications of diagnostic hysteroscopy, a brief review of the literature. Gynecol Surg. 2012;9:23-8.

2. Elbareg AM, Elmahashi MO, Essadi FM. Evaluation of intrauterine pathology: efficacy of diagnostic hysteroscopy in comparison to histopathological examination. Reprod Syst Sex Disord. 2015;4(2):149.

3. Tangri MK, Lele P, Kapur K, Kapur A, Chabbra N, Mitra B, et al. Role of office hysteroscopy in gynecology: retrospective observational study at a tertiary care hospital. Int J Reprod Contracept Obstet Gynecol. 2017;6(1):111-6.

4. Gulumser C, Narvekar N, Pathak M, Palmer E, Parker S, Saridogan E. See-and-treat outpatient hysteroscopy: an analysis of 1109 examinations. Reprod Biomed Online. 2010;20(3):423-9.

5. Emovon E, Ranganathan A, Tumula S. Outpatient hysteroscopy: the Calderdale and Huddersfield experience. Clinical Audit. 2010;2:121-5.

6. Kathuria R, Bhatnagar B. Correlation between D and $\mathrm{C}$, USG and hysteroscopy findings in diagnosing a cause for abnormal uterine bleeding. Indian $\mathrm{J}$ Clin Pract. 2014;25(5):466-70.

7. Loffer FD. Contraindications and complications. In: Obstetrics and Gynecology Clinics of North America: Hysteroscopy. AM Siegler, eds. Philadelphia: WB Saunders; 1995:445-72.

8. Loffer FD. Complications of Hysteroscopy-their cause, prevention and correction. J Am Assoc Gynecol Laparosc. 1995;3(1):11-26.

9. Deora S, Manchanda R, Ashraf S. Clinical audit of operative hysteroscopy and it's complications in a single institute performed by the same surgeon in the duration of four years. Int $\mathrm{J}$ Scient Res. 2018;7(1):683-4.

10. Pasini A, Belloni C. Intraoperative complications of 697 consecutive operative hysteroscopies. Minerva Ginecol. 2001;53(1):13-20.

11. Tarneja P, Tarneja VK, Duggal BS. Complications of hysteroscopic surgery. Med J Armed Forces India. 2002;58(4):331-4.

Cite this article as: Upadhyay M, Yadav TC, Lakra P, Siwach S, Mahendru R, Sangwan V. Experience of hysteroscopy in a rural tertiary care center of Haryana, India. Int J Reprod Contracept Obstet Gynecol 2019;8:3996-9. 